\title{
FÁS SZÁRÚ BIOMASSZÁK PIROLÍZISÉNEK TERMOKINETIKAI MODELLEZÉSE
}

\section{THERMOKINETIC MODELLING OF WOOD BIOMASS PYROLYSIS}

\author{
Bodnár István ${ }^{1}$, Plásztán Bence ${ }^{2}$ \\ ${ }^{1}$ Miskolci Egyetem, Gépészmérnöki és Informatikai Kar, Elektrotechnikai és Elekt- \\ ronikai Intézet, Magyarország, 3515 Miskolc-Egyetemváros; Tel: +36 46565 142, \\ vegybod@uni-miskolc.hu \\ ${ }^{2}$ Miskolci Egyetem, Gépészmérnöki és Informatikai Kar, Energetikai és Vegyipari \\ Gépészeti Intézet, Vegyipari Gépészeti Intézeti Tanszék, Magyarország, 3515 Mis- \\ kolc-Egyetemváros; Tel: +36 46565 168, bence.plasztan@gmail.com
}

\begin{abstract}
The optimal parameters of the Pyrolysis Technology have been investigated. During the thermokinetic modelling of the procedure pyrolysis of different biomasses with chemical composition have been analysed. The modelling has been executed with different wood biomass at different percentages of moisture. On the basis of the wood's chemical composition and of the reaction equation we have made an approximate model, which helps to specify the resulting pyrolysis gas' chemical composition and the energetic properties. The results have been compared with the required reaction efficiency and with the energy generation.
\end{abstract}

Keywords: biomass, pyrolysis, efficiency, modelling

\section{Összefoglalás}

A pirolízistechnológia optimális üzemi paramétereit keressük. A folyamatok termokinetikai modellezése során eltérő kémiai összetételü biomasszák pirolízisét vizsgáltuk. A modellezést különböző hőmérsékleteken, a nedvességtartalom mértékének figyelembevételével végeztük. Egységnyi faanyag pirolízise során keletkezett gázok energetikai tulajdonságait határoztuk meg, és összevetettük a reakcióhoz szükséges energiaigénnyel.

Kulcsszavak: biomassza, pirolizis, hatékonyság, modellezés

\section{Bevezetés}

A fás szárú biomasszák hasznosítása egyidős az emberiség történelmével. Az emberiség létezése óta arra törekedett, hogy számára hasznossá tegye a természet által rendelkezésre bocsátott energiaforrásokat. Kezdetben szinte kizárólag megújuló energiaforrásokat alkalmaztunk, mint a bio- massza, a víz, a szél és a napenergia. Az ipari forradalom idején a kőszéntelepek felfedezése, a XIX. század második felétől kezdődően a kőolaj- és a földgázlelőhelyek feltárása kiszorította a megújuló energiaforrásokat az energiaiparban, amelyek jellemzően a XX. században kerültek újra előtérbe. A megújulóenergia-források közül kiemelkedő a biomassza, amely folyamatos 
erőmü-üzemeltetést tesz lehetővé a szakaszos napenergián és szélenergián alapuló, ingadozó teljesítményü rendszerekhez képest.

A biomassza alapú energiatermelés, tehát a korszerü biomasszatüzelés az elmúlt években egyre népszerübbé vált. Ennek oka egyrészt a hagyományos, fosszilis alapú tüzelőanyagok viszonylag magas ára és mennyiségi korlátja, másrészt a környezettudatosság; valamint a fenntartható energiatermelés és -fogyasztás mint alapelv megjelenésére vezethető vissza.

A világ favagyona megközelítőleg 300 milliárd köbméterre tehető. Ebből évente átlagosan 3-4 milliárd köbméter kerül kitermelésre, aminek az egyik fele ipari, a másik fele pedig kémiai (rostanyag) és energetikai (tüzelőanyag) hasznosításra kerül [18]. Magyarország területének közel $20 \%$-át erdő fedi, Európát tekintve ez az arány 45\%. Hazánk 1,9 millió hektár erdőterületének faállománya mintegy 330 millió $\mathrm{m}^{3}$-re tehető. Évente közel 11 millió $\mathrm{m}^{3}$ a fanövekmény (folyónövedék), ami átlagosan 30 éves megújulási ciklusidőt jelent. Az éves energiahozam 160 PJ. Erdőink nagyobb részét, körülbelül $86 \%$-át lombhullató fák képezik, akác (több mint 50\%), cser, tölgyek, bükk, gyertyán, fenyő és egyéb lombos fák. Ennek megfelelöen a hazai biomasszapotenciál 328 PJ-ra tehető, amiből jelenleg 49,2 PJ kerül hasznosításra, ez 15\%-os hasznosítási arányt jelent [18].

$\mathrm{Az}$ energiatermelésre hasznosítható faanyag (energiafa) a kitermelt lombos fáknak a felét, a fenyőknek alig a 20\%-át teszi ki. Az évente kitermelhető energiafa 4-4,5 millió $\mathrm{m}^{3}$-re becsülhető. A száraz fa fütőértéke 17-20 MJ/kg. Ezen számok alapján a hazai erdők évi energiafa-potenciálja 56 PJ-re becsülhető [18]. A biomassza a benne rejlő lehetőségnek köszönhetően a terület- és a településfejlesztésben, valamint a kistérségek munkahelyteremtésében kiemelt szerepet játszhat, ami ezáltal szerves részét képezheti a közmunkaprogramnak. A biomasszán alapuló fejlesztések lehetőséget adnak továbbá „,falufütőmüvek” és villamos erőmüvek létesítésére, amik nemcsak zöldenergiát termelnek, hanem bevételi forrást jelenthetnek a települések számára.

Mindazonáltal nem szabad elfelejteni, hogy a biomassza egy olyan megújuló energiaforrás, amely véges kapacitással áll a rendelkezésünkre, ezért a megújítható energiaforrás megnevezés lenne a helytálló. Túlzott kiaknázása a környezet elhasználódásához vezet, ami azt jelenti, hogy már a megújuló energiaforrások sem képesek újratermelődni, mert a fogyasztási folyamat gyorsabb, mint azok megújulási ciklusideje. Ebből következik, hogy elsősorban az erdészeti és a faipari feldolgozás során keletkező melléktermékek, hulladékok termikus hasznosításában célszerü gondolkozni és alternatív tüzeléstechnikákat alkalmazni.

\section{Pirolízis}

A pirolízis a szerves anyagok höbontásán alapuló folyamat, ami jellemzően az oxigén teljes kizárása mellett játszódik le. Mivel a biomasszában az oxigén kémiailag jelen van, ezért kezelése során nem beszélhetünk tökéletes pirolízisről. Szerves hulladékok kezelése egy arra a célra megfelelően kialakított, rendszerint nyomás vagy vákuum alatt lévő, hő hatására bekövetkező kémiai bomlással történő átalakítást jelent [1]. A kezelés során gáz halmazállapotú energiahordozó szabadul fel, amit pirolízisgáznak vagy pirogáznak nevezünk.

A pirogáz döntően szén-monoxidban és hidrogénben, valamint metánban gazdag gázelegy, amelynek fütőértéke megközelítheti a földgáz fütőértékét az energetikailag inert összetevők leválasztását követően. Az energetikailag inert összetevőket föleg a szén-dioxid, a vízgőz és esetekben a nitrogén teszi ki, amelyek leválasztása körülményes. A gáztermékben előfordulhatnak fémgőzök, por, és szervetlen vegyületek, amelyek jó hatásfokkal leválaszthatók [2]. 
A gáztermék erőművi hasznosítása elsősorban gázmotoros rendszerekben célszerü, amely így alkalmassá teheti a földgáz üzemü erömüvek kiváltását [3].

Szilárd fázisban pirolíziskoksz, röviden pirokoksz marad vissza, amiben a betáplált alapanyag karbon tartalma feldúsul [4]. Az így előállított energiahordozó a vaskohászatban, a cementgyártásban, valamint a széntüzelésü erőmüvekben alkalmazható kőszén kiváltására. Nehéz- és könnyüfémekkel szennyezett hulladék esetében a fémek rendszerint szilárd fázisban maradnak vissza, így azok visszanyerésére további kezelésnek vetik alá a pirokokszot [5].

Folyékony fázisban úgynevezett pirolízisolaj, piroolaj keletkezik, amely szén-hidrogéneket és kátrányt tartalmaz [4]. A klasszikus pirolízis hőmérséklet-tartományában $\left(>600{ }^{\circ} \mathrm{C}\right)$ a folyadékfázis keletkezése csekély valószínúségü. Megfelelö tisztítást és lepárlást követően akár különféle üzemanyagok is gyárthatók belőle, így a közlekedésben is alkalmazható haszontermékek állíthatók elő [6]. A keletkező termékek arányát az alkalmazott hőmérséklet, az alapanyag nedvességtartalma, valamint a kezelési idő jelentősen befolyásolja [5]. A nagyobb hőmérséklet és nedvességtartalom, valamint a hosszabb kezelési idő kedvez a gázhozamnak, mivel megnöveli a szénláncok elbomlásának valószínüségét. Emellett az sem elhanyagolható, hogy a kezelési idő növekedésével a kokszolódás mértéke is megnő, ami káros a folyamatokra nézve. [7].

A pirolízis a hagyományos égetéshez hasonlóan a termikus kezelési eljárások közé tartozik, de alapjában véve két különböző folyamatról beszélünk. Az égetéshez három lényeges dolog szükséges, ami az éghető anyag, az oxidálóanyag és a megfelelö égéstéri hőmérséklet. Ezzel ellentétben a pirolízis során csak éghető anyagra és höre van szükség [8].

A gyakorlatban nem beszélhetünk tökéletes pirolízisről, mert maga a tüzelőanyag is tartalmaz valamekkora mértékben oxigént, így szén-monoxid, szén-dioxid, vízgőz valamint kén- és nitrogén-oxidok is keletkeznek [4]. További eltérés, hogy az égés hőtermelö, tehát exoterm folyamat, míg a pirolízis endoterm, azaz fenntartásához hőt igényel, amit rendszerint villamos fütéssel visznek a rendszerbe, de alkalmazható közvetlen vagy köpenyfütés is a felszabaduló forró pirolízisgáz visszacirkuláltatásával.

A joggyakorlatban a pirolízis, ahogy a többi alternatív termikus technológia, nem különbözik a hagyományos égetéstöl, de müszaki értelemben egyik üzem sem tekinthető hagyományos égető rendszernek, mert különböző kémiai folyamatok játszódnak le az egyes technológiáknál. Az alternatív technológiák társadalmi megítélése, a környezeti és gazdasági hatásai mégis azonosak, mint a hagyományos hulladékégetőknek [2].

A pirolízis egy olyan gyüjtőfogalom, amely több technológiát is magába foglal. $\mathrm{Az}$ egészen kis hőmérsékletü $\left(<300{ }^{\circ} \mathrm{C}\right)$ eljárás, mint a pörkölés (torrefaction) legfőbb célja a tüzelőanyagban lévő illékony vegyületek eltávolítása és a nedvességtartalom csökkentése, így a visszamaradó szilárd termék energiasürüségének növelése. A szintén kis hőmérsékletü, $410-450{ }^{\circ} \mathrm{C}$ közötti hőmérséklettartományban alkalmazott krakkolással üzemanyagok állíthatók elő.

A kokszosítás, más nevén a svélezés cél-ja a pörköléshez hasonlóan olyan szilárd végtermék előállítása, amelyben a karbon feldúsul. A folyamat során felszabaduló gáztermék elégetésével a technológia energiaigénye fedezhető. Az alkalmazott hőmérséklet rendszerint a $400-600{ }^{\circ} \mathrm{C}$ tartományban található [2].

A klasszikus pirolízis a hulladék, illetve tüzelőanyag szerves molekuláinak a hőbontását valósítja meg $500-800{ }^{\circ} \mathrm{C}$-on, aminek eredményeként gáznemü és szilárd frakció jön létre. Ezen belül beszélhetünk lassú és gyors pirolízisről [2]. 
A pirolízist gyakran kiegészítik gázosítással. A kigázosítás a pirolíziskokszban maradó szén folyamatgázzá (pirolízisgázzá) történő átalakítását jelenti $800-1.000{ }^{\circ} \mathrm{C}$ on. Mivel a folyamat során gázosodást segítő anyag (pl. levegö, tiszta oxigén) jelenléte szükséges, ezért ezt a megoldást a legtöbb szakirodalom már a gázosításhoz sorolja. A gyakorlatban ezt a kialakítást pirolitikus elgázosításnak is nevezik.

\section{Fás szárú biomasszák kategori- zálása}

A fás szárú biomasszák pirolízissel történő kezelésére, hasznosítására vonatkozóan termokinetikai modellvizsgálatokat végeztünk, amelyek a moláris anyagmegmaradás tételén alapulnak. A modellegyenlet fel-írásához ismerni kell az alapanyag egymólnyi karbontartalmára vonatkozó, fajlagos kémiai összetételét tömegszázalékban. Az (1) összefüggés mutatja a hulladék egymólnyi karbontartalomra vonatkozó hidrogén és az oxigén-tartalom-átszámítást, valamint mutatja a felírási formalizmust [9]:

$$
\begin{aligned}
& a_{C} \cdot C+a_{H} \cdot H+a_{O} \cdot O= \\
& C_{a_{C}}+H_{a_{H}}+O_{a_{O}}=C+H \frac{a_{H}}{a_{C}}+O O_{\frac{a_{O}}{a_{C}}}= \\
& C_{\frac{a_{H}}{a_{C}}} O_{\frac{a_{O}}{a_{C}}}=C H_{k} O_{l},
\end{aligned}
$$

ahol:

$\mathrm{a}_{\mathrm{C}}$ a tüzelőanyag moláriskarbontartalma, $\mathrm{a}_{\mathrm{H}}$ a hidrogéntartalma

$\mathrm{a}_{\mathrm{O}}$ az oxigéntartalma [ $\mathrm{mol} / \mathrm{kg}_{\text {tüzelöanyag }}$;

$\mathrm{k}$ és 1 a tüzelöanyag egymólnyi karbontartalmára vonatkoztatott hidrogén- és oxigéntartalma, tehát a $\mathrm{H} / \mathrm{C}$ és az $\mathrm{O} / \mathrm{C}$ arány.

Néhány jellegzetes fafajta $\mathrm{H} / \mathrm{C}$ és $\mathrm{O} / \mathrm{C}$ arányát szemlélteti az 1. táblázat, amiket az elemi összetételek függvényében az ismertetett módon határoztuk meg.
1. táblázat. Fafajták $H / C$ és $O / C$ arányai a száraz bázisra vonatkoztatva

\begin{tabular}{|l|l|l|l|l|l|}
\hline & Akác & Bükk & Fenyö & Nyár & Tölgy \\
\hline H/C & 1,42 & 1,45 & 1,45 & 1,45 & 1,20 \\
\hline O/C & 0,66 & 0,60 & 0,65 & 0,60 & 0,56 \\
\hline
\end{tabular}

A táblázatból látható, hogy az egyes fafajták fajlagos összetételüket tekintve széles skálán mozognak, ezért a fás szárú biomasszák kémiai összetétele alapján készítettünk egy összefoglaló táblázatot (2. táblázat), amely a $\mathrm{H} / \mathrm{C}$ és az $\mathrm{O} / \mathrm{C}$ arányok alapján tartalmazza az egyes fajtákat. Összesen 46 kategóriát különítettünk el, ami jellemzően lefedi az ismert fafajtákat, valamint a fahulladékokat [10]. A feltüntetett arányok alapján elkészítettük az elemzéseket pirolízisre, $500{ }^{\circ} \mathrm{C}$ hőmérsékletü kezelés mellett, változó nedvességtartalom esetében.

2. táblázat. Fás szárú biomasszák $H / C$ és $O / C$ kategóriái [-]

\begin{tabular}{|c|c|c|c|c|c|c|}
\hline $\mathbf{H} / \mathbf{C}$ & $\mathbf{O} / \mathbf{C}$ & $\mathbf{O} / \mathbf{C}$ & $\mathbf{O} / \mathbf{C}$ & $\mathbf{O} / \mathbf{C}$ & $\mathbf{O} / \mathbf{C}$ & $\mathbf{O} / \mathbf{C}$ \\
\hline $\mathbf{1 , 1 5}$ & - & 0,45 & 0,50 & 0,55 & - & - \\
\hline $\mathbf{1 , 2 0}$ & - & 0,45 & 0,50 & 0,55 & 0,60 & - \\
\hline $\mathbf{1 , 2 5}$ & 0,40 & 0,45 & 0,50 & 0,55 & 0,60 & - \\
\hline $\mathbf{1 , 3 0}$ & 0,40 & 0,45 & 0,50 & 0,55 & 0,60 & 0,65 \\
\hline $\mathbf{1 , 3 5}$ & 0,40 & 0,45 & 0,50 & 0,55 & 0,60 & 0,65 \\
\hline $\mathbf{1 , 4 0}$ & 0,40 & 0,45 & 0,50 & 0,55 & 0,60 & 0,65 \\
\hline $\mathbf{1 , 4 5}$ & 0,40 & 0,45 & 0,50 & 0,55 & 0,60 & 0,65 \\
\hline $\mathbf{1 , 5 0}$ & - & - & 0,50 & 0,55 & 0,60 & 0,65 \\
\hline $\mathbf{1 , 5 5}$ & - & - & 0,50 & 0,55 & 0,60 & 0,65 \\
\hline $\mathbf{1 , 6 0}$ & - & - & - & - & 0,60 & 0,65 \\
\hline
\end{tabular}

\section{Termokinetikai modell alapegyen-} letei

A termokinetikai modellvizsgálat során meghatároztuk az egyes alapanyagokból előállított gáztermékek kémiai és energetikai tulajdonságait. A folyamatok modellezésére termokinetikai modellt alkalmaztunk, ami a moláris tömeg- és energiamegmaradás tételén alapul [9]. A modell alkalmazásával közelítő becslést lehet adni a keletkező gáz kémiai összetételére, fütőér- 
tékére, viszkozitására és a lejátszódó kémiai reakciók energetikai hatékonyságára. Mivel a modell lényege, hogy egyszerübbé és gyorsabbá tegye a számítást, ezért az egyszerüsített modellegyenletek felírásakor egyes összetevőket, mint például a nitrogén-oxidokat, valamint az etilén- és acetilén-vegyületeket elhanyagoltuk. A modellegyenlet a tüzelőanyag egymólnyi karbontartalmára vonatkoztatott hidrogén- és oxigéntartalmára kerül felírásra $[9,11,12]$.

A modellvizsgálatokat az egyensúlyi állandók módszerével, előre definiált elemi összetételü alapanyagra vonatkozóan, rögzített hőmérséklet és üzemi nyomás mellett végeztük el. Az egyensúlyi állandók módszere a megadott hőmérsékleten az egyensúlyi átalakuláshoz tartozó számítás. Lényege, hogy a Gibbs-féle szabadenergia minimalizálásának elve alapján határozzuk meg a vizsgált folyamatok során keletkező termékek összetételét [13]. Az elemzések elkészítéséhez a Gaseq nevü, a NASAmódszeren alapuló szoftvert alkalmaztuk, amit Chris Morley fejlesztett ki, és mindenki számára térítésmentesen elérhető, valamint szabadon felhasználható oktatási és nem profitorientált célokra. Elsősorban gázfázisú reagensek kölcsönhatását leíró egyenletek megoldására használható, de a termikus kezelési technológiák termokinetikai folyamatainak szimulálására is alkalmas. Abban az esetben, ha az elméleti és az alkalmazott moláris oxigénigény aránya egyenlő eggyel $(\lambda=1)$, vagy egynél nagyobb, akkor visszakapjuk az égési egyenleteket.

A kibővített modellegyenlet a moláris anyagmegmaradás tétele alapján a következő módon írható fel:

$$
\begin{aligned}
& \mathrm{CH}_{k} \mathrm{O}_{l}+n_{m} \cdot \mathrm{H}_{2} \mathrm{O}+a \cdot \mathrm{N}_{2}=x_{1} \cdot \mathrm{H}_{2}+x_{2} \cdot \\
& \mathrm{CO}+x_{3} \cdot \mathrm{H}_{2} \mathrm{O}+x_{4} \cdot \mathrm{CO}_{2}+x_{5} \cdot \mathrm{CH}_{4}+x_{6} \\
& \mathrm{O}_{2}+x_{7} \cdot \mathrm{NO}+x_{8} \cdot \mathrm{NO}_{2}+x_{9} \cdot \mathrm{N}_{2}+x_{10} . \\
& \mathrm{N}_{2} \mathrm{O}+x_{11} \cdot \mathrm{C}+x_{i} \cdot \mathrm{C}_{d} \mathrm{H}_{f} \mathrm{O}_{g}
\end{aligned}
$$

ahol:

$\mathrm{n}_{\mathrm{m}}$ a tüzelőanyag egymólnyi karbontartalmára vonatkoztatott nedvességtartalma,

$\mathrm{a}_{\mathrm{a}}$ a tüzelőanyag nitrogéntartalma,

$\mathrm{x}_{1}$ a keletkező nyers szintézisgáz moláris hidrogéntartalma,

$\mathrm{x}_{2}$ a szén-monoxid-tartalma,

$\mathrm{x}_{3}$ a vízgőztartalma,

$\mathrm{x}_{4}$ a szén-dioxid-tartalma,

$\mathrm{x}_{5}$ a metántartalom,

$\mathrm{x}_{6}$ a maradó oxigéntartalom,

$\mathrm{x}_{7}$ a nitrogén-monoxid,

$\mathrm{x}_{8}$ a nitrogén-dioxid tartalom,

$\mathrm{X}_{9}$ a nitrogéntartalom,

$\mathrm{x}_{10}$ a dinitrogén-oxid-tartalom,

$\mathrm{x}_{11}$ a visszamaradt szilárd karbon,

$\mathrm{x}_{\mathrm{i}}$ a keletkező egyéb összetevők moláris mennyisége (pl. etilén, acetilén).

A modellvizsgálatok arra irányultak, hogy meghatározzuk a keletkező gáztermék kémiai összetételét, amiből származtatni tudjuk a technológiai, valamint az energetikai hatékonyságot jellemző tulajdonságokat és paramétereket.

A paraméteres alapegyenletek megadása azért szükséges, mert ezeket felhasználva építettük fel a modellvizsgálatokat. A bemeneteli összetételek függvényében és a keletkező termékek ismeretében felírt 2. képlet egyenlőségjelének jobb oldalán található ismeretlen mennyiségek meghatározására, azaz az egyenlet megoldására az egyensúlyi állandók módszerét választottuk.

Alkalmaztuk az egyensúlyi állandók módszerét, amihez előbb felírtuk minden egyes komponensre a moláris anyagmérleg egyenletet, és ellenőriztük, hogy teljesül-e a moláris anyagmegmaradás tétele (3-5. öszszefüggések), végül meghatároztuk az egyensúlyi állandókat (6-7. képlet) $[9,12]$ :

Karbonegyensúly:

$$
1=x_{2}+x_{4}+x_{5}
$$

Hidrogénegyensúly:

$$
k+2 \cdot n_{m}=2 \cdot x_{1}+2 \cdot x_{3}+4 \cdot x_{5}
$$


Oxigénegyensúly:

$l+n_{m}=x_{2}+x_{3}+2 \cdot x_{4}+2 \cdot x_{6}$

Víz-gáz reakcióegyensúlyi állandó:

$K_{1}=\frac{x_{1} \cdot x_{4}}{x_{2} \cdot x_{3}}$

Metánképződési egyensúlyi állandó:

$$
K_{2}=\frac{x_{5}}{x_{1}^{2}}
$$

ahol $\mathrm{K}_{1}$ és $\mathrm{K}_{2}$ a víz-gáz és a metánképződés egyensúlyi állandók, amik függnek a hömérséklettől és a nyomástól. A modellezés során állandó $500{ }^{\circ} \mathrm{C}$ hőmérsékleten és állandó 1 bar üzemi nyomáson vizsgálódtunk.

$\mathrm{Az}$ egyes keletkező termékek moláris mennyiségben kifejezett értékét az egyensúlyi mólszámmal (x) jelöljük. Az egyensúlyi mólszám megmutatja, hogy a keletkező komponens milyen mennyiségben keletkezik a többi termékkomponenshez képest.

A Gibbs-féle szabadenergia az egyensúlyi számok, a nyomás és a hőmérséklet függvényében a (8.) képlet alapján írható fel $[9,14]$ :

$\frac{G}{R \cdot T}=\sum_{i=1}^{n}\left(\frac{x_{i} \cdot G_{i}^{0}}{R \cdot T}+x_{i} \cdot \ln \frac{x_{i}}{\sum x_{i}}+x_{i} \cdot \ln p\right)$

ahol $\mathrm{G}$ a Gibbs-féle szabadenergia, $\mathrm{G}_{\mathrm{i}}{ }^{0}$ az iedik alapanyag $1 \mathrm{~mol}$ anyagmennyiségre vonatkoztatott fajlagos szabadenergiája atmoszferikus nyomáson, $\mathrm{R}$ az egyetemes gázállandó, $\mathrm{T}$ a rendszer hőmérséklete, $\mathrm{p}$ a rendszer nyomása, $\mathrm{x}_{\mathrm{i}}$ az i-edik komponens egyensúlyi mólszáma, azaz az i-edik alapanyag anyagmennyisége a keverékben, $\mathrm{n}$ a kémiai elemek száma, $\sum \mathrm{x}_{\mathrm{i}}$ a végtermék egyensúlyi mólszámainak összege, a keverék anyagmennyisége.

Termodinamikai egyensúlyi állapotban a G/RT hányados minimalizálása a cél, amit az elemi összetétel határoz meg.

A modellvizsgálatok során a modellegyenletek megoldására a Gaseq szoftverben az állandó nyomáson és hőmérsékleten vett egyensúlyi állandók módszerét alkal- maztuk. A szoftvert kémiai egyensúlyi folyamatok elemzése céljából fejlesztették ki, így használata megfelelö a termikus kezelési technológiák vizsgálatára. A kezelési folyamatok szimulálásával megfigyelhettük, hogy a bemenő paraméterek változtatása hogyan befolyásolja a pirolízis során keletkező gáztermék összetételét.

\section{Energetikai hatékonyságvizsgálat}

Az energiahatékonyság napjaink egyik kulcsfontosságú kérdése. Az energiahatékonysági politika szorosan kapcsolódik a kereskedelmi, az ipari versenyképesség, valamint az energiabiztonsági tevékenységekhez, de egyre fontosabbá vált a környezetvédelmi elönyök, mint a szén-dioxidkibocsátás csökkentésére irányuló törekvések egyik alapeszközeként [15]. Az energia átalakításának hatékonyságára számos hagyományos és nem konvencionális mérōszám ismert és alkalmazható. A következőkben három nem konvencionális paramétert mutatunk be.

A reakció- vagy más néven a kémiai hatásfok (9.) megmutatja, hogy a szilárd tüzelőanyag energiatartalmának mekkora része jelenik meg az előállított gáztermékben [16, 17]. A reakcióhatásfok ismeretében meghatározható az égetés tökéletességét jellemző paraméter. Számítási módszerét a (10.) képlet mutatja. Ezek alapján:

$$
\begin{aligned}
& \eta_{r}=\frac{m_{g t} \cdot F_{g t}}{m_{s z t}^{\cdot} \cdot F_{s z t}} \\
& \eta_{\text {é }}=1-\eta_{\mathrm{r}}
\end{aligned}
$$

ahol: $\eta_{\mathrm{r}}$ a reakcióhatásfok, $\left(\mathrm{m}_{\mathrm{gt}}\right)$ a gáztermék tömegárama, $\mathrm{F}_{\mathrm{gt}}$ a gáztermék fütőértéke, $\left(\mathrm{m}_{\mathrm{szt}}\right)$ a szilárd tüzelöanyag tömegárama, $F_{s z t}$ a tüzelőanyag fütőértéke és $\prod_{\text {é }} a z$ égési hatásfok.

A fajlagos energiakihozatal megmutatja, hogy egységnyi tömegü bemenő szilárd tüzelöanyagra vonatkoztatva mekkora energiamennyiség állítható elő. Felhasználásá- 
val közvetlenül számítható az eredő energiakonverziós hatásfok.

A fajlagos energiakihozatal a (11.) öszszefüggéssel írható fel

$$
\mathrm{e}_{\mathrm{k}}=\frac{\mathrm{m}_{\mathrm{gt}} \cdot \mathrm{F}_{\mathrm{gt}}}{\mathrm{m}_{\mathrm{szt}}}=\eta_{\mathrm{r}} \cdot \mathrm{F}_{\mathrm{szt}}
$$

ahol $\mathrm{e}_{\mathrm{k}}$ a fajlagos energiakihozatal.

Energetikai szempontból van egy lényeges technológiai paraméter, a fajlagos gáztermelés, amely megmutatja, hogy egy $\mathrm{kg}$ tüzelőanyagból (a segédgázokat is figyelembe véve) hány $\mathrm{kg}$ gáztermék állítható elő [10]. A fajlagos gáztermelés

$$
k_{g t}=\frac{m_{g t}}{m_{s z t}}
$$

ahol $\mathrm{k}_{\mathrm{gt}}$ a fajlagos gáztermelés.

Pirolízis esetében a gáztermék mellett éghető piroolaj és pirokoksz is keletkezik, amikre vonatkozóan szintén meghatározható a fajlagos pirokokszkihozatal $\left(\mathrm{k}_{\mathrm{pk}}\right)$, és a fajlagos piroolajkihozatal $\left(\mathrm{k}_{\mathrm{po}}\right)$ mértéke. A fajlagos kihozatalok összege egyet ad.

A 46 fás szárú biomassza kategóriákra vonatkozóan a pirolízist folyamatos üzemben vizsgáltuk. A reakció-hőmérsékletet $500{ }^{\circ} \mathrm{C}$-ra választottuk, és segédgázt nem alkalmaztuk. Az alkalmazott üzemi nyomás 1 bar. Az ismertetésre kerülő hatékonyságmátrixok e reakciókörülményekre vonatkoznak.

A felállított modell és az így kapott eredmények maximum 35\%-os nedvességtartalmú fás szárú biomasszára alkalmazhatók. A modellezés folyamata során a száraz fa és a 35\%-os nedvességtartalom közötti tartományban a nedvesség hatása lineáris függvénnyel írható le. 35\%-nál nagyobb nedvességtartalom esetében a linearizált modell nem alkalmazható, mivel nagyobb nedvességtartalom esetében a modell 100\%-nál nagyobb kémiai hatásfokot eredményez.

Az energetikai hatékonyságot jellemző paraméterek közül, kiindulásként a fajlagos energiakihozatalt határoztuk meg az előallí- tott pirolízisgáz kémiai összetétele alapján (3. és 4. táblázat).

3. táblázat. Fajlagos energiakihozatal mértéke pirolizisnél, $e_{k}\left[\mathrm{MJ} / \mathrm{kg}_{f a}\right]$

\begin{tabular}{|c|c|c|c|}
\hline $\mathbf{H} / \mathbf{C} ; \mathbf{O} / \mathbf{C}$ & $\mathbf{0 , 4 0}$ & $\mathbf{0 , 4 5}$ & $\mathbf{0 , 5 0}$ \\
\hline $\mathbf{1 , 1 5}$ & - & 5,0557 & 4,6962 \\
\hline $\mathbf{1 , 2 0}$ & - & 5,3548 & 4,9392 \\
\hline $\mathbf{1 , 2 5}$ & 5,7804 & 5,5874 & 4,9653 \\
\hline $\mathbf{1 , 3 0}$ & 6,0386 & 5,7008 & 5,1989 \\
\hline $\mathbf{1 , 3 5}$ & 6,2317 & 5,8263 & 5,3213 \\
\hline $\mathbf{1 , 4 0}$ & 6,2237 & 5,9501 & 5,4605 \\
\hline $\mathbf{1 , 4 5}$ & 6,4525 & 5,9798 & 5,5505 \\
\hline $\mathbf{1 , 5 0}$ & - & - & 5,5769 \\
\hline $\mathbf{1 , 5 5}$ & - & - & 5,6990 \\
\hline $\mathbf{1 , 6 0}$ & - & - & - \\
\hline
\end{tabular}

4. táblázat. Fajlagos energiakihozatal mértéke

\begin{tabular}{|c|c|c|c|}
\multicolumn{4}{c}{ pirolizisnél, $e_{k}\left[\mathrm{MJ} / \mathrm{kg}_{\text {fa }}\right]$} \\
\hline $\mathbf{H} / \mathbf{C} ; \mathbf{O} / \mathbf{C}$ & $\mathbf{0 , 5 5}$ & $\mathbf{0 , 6 0}$ & $\mathbf{0 , 6 5}$ \\
\hline $\mathbf{1 , 1 5}$ & 4,6143 & - & - \\
\hline $\mathbf{1 , 2 0}$ & 4,6350 & 4,4128 & - \\
\hline $\mathbf{1 , 2 5}$ & 4,7949 & 4,4936 & - \\
\hline $\mathbf{1 , 3 0}$ & 4,8707 & 4,5893 & 4,1822 \\
\hline $\mathbf{1 , 3 5}$ & 5,0088 & 4,5337 & 4,3322 \\
\hline $\mathbf{1 , 4 0}$ & 5,0723 & 4,7053 & 4,4967 \\
\hline $\mathbf{1 , 4 5}$ & 5,0955 & 4,7363 & 4,4724 \\
\hline $\mathbf{1 , 5 0}$ & 5,1337 & 4,8342 & 4,4310 \\
\hline $\mathbf{1 , 5 5}$ & 5,2298 & 4,7961 & 4,5427 \\
\hline $\mathbf{1 , 6 0}$ & - & 4,8978 & 4,7612 \\
\hline
\end{tabular}

Megfigyelhetö, hogy az alapanyag H/C arányának növekedése nagyobb fajlagos energiakihozatalt eredményez, míg az O/C aránynál fordított tendencia tapasztalható. Míg előbbi esetben jellemzően hidrogénfelszabadulással, utóbbinál szén-dioxid- és vízgőzképződéssel számolhatunk.

A nedvességtartalom fajlagos energiakihozatalra gyakorolt hatását az 5 . és $\mathbf{6}$. táblázatból olvashatjuk le, amely 10\%-os nedvességtartalom-növekedésre vonatkozik. Látható, hogy a növekvő nedvességtartalom pirolízis alkalmazása során pozitív irányban befolyásolja a fajlagos energiakihozatalt. 
5. táblázat. 10\%-os nedvességtartalom hatása a fajlagos energiakihozatalra, $\Delta e_{k}\left[\mathrm{MJ} / \mathrm{kg}_{\mathrm{fal}}\right]$

\begin{tabular}{|c|c|c|c|}
\hline $\mathbf{H} / \mathbf{C} ; \mathbf{O} / \mathbf{C}$ & $\mathbf{0 , 4 0}$ & $\mathbf{0 , 4 5}$ & $\mathbf{0 , 5 0}$ \\
\hline $\mathbf{1 , 1 5}$ & - & 0,5436 & 0,5796 \\
\hline $\mathbf{1 , 2 0}$ & - & 0,5129 & 0,5553 \\
\hline $\mathbf{1 , 2 5}$ & 0,4696 & 0,4896 & 0,5528 \\
\hline $\mathbf{1 , 3 0}$ & 0,4423 & 0,4778 & 0,5294 \\
\hline $\mathbf{1 , 3 5}$ & 0,4223 & 0,4655 & 0,6145 \\
\hline $\mathbf{1 , 4 0}$ & 0,4236 & 0,4528 & 0,5029 \\
\hline $\mathbf{1 , 4 5}$ & 0,4003 & 0,4497 & 0,4942 \\
\hline $\mathbf{1 , 5 0}$ & - & - & 0,4914 \\
\hline $\mathbf{1 , 5 5}$ & - & - & 0,4795 \\
\hline $\mathbf{1 , 6 0}$ & - & - & - \\
\hline
\end{tabular}

6. táblázat. $10 \%$-os nedvességtartalom hatása a fajlagos energiakihozatalra, $\Delta e_{k}\left[M J / \mathrm{kg}_{f a}\right]$

\begin{tabular}{|c|c|c|c|}
\hline $\mathbf{H} / \mathbf{C} ; \mathbf{O} / \mathbf{C}$ & $\mathbf{0 , 5 5}$ & $\mathbf{0 , 6 0}$ & $\mathbf{0 , 6 5}$ \\
\hline $\mathbf{1 , 1 5}$ & 0,5875 & - & - \\
\hline $\mathbf{1 , 2 0}$ & 0,5849 & 0,6069 & - \\
\hline $\mathbf{1 , 2 5}$ & 0,5702 & 0,5990 & - \\
\hline $\mathbf{1 , 3 0}$ & 0,5623 & 0,5892 & 0,6274 \\
\hline $\mathbf{1 , 3 5}$ & 0,5485 & 0,5942 & 0,6131 \\
\hline $\mathbf{1 , 4 0}$ & 0,5417 & 0,5774 & 0,5971 \\
\hline $\mathbf{1 , 4 5}$ & 0,5388 & 0,5739 & 0,5986 \\
\hline $\mathbf{1 , 5 0}$ & 0,5353 & 0,5647 & 0,6024 \\
\hline $\mathbf{1 , 5 5}$ & 0,5264 & 0,5676 & 0,5914 \\
\hline $\mathbf{1 , 6 0}$ & - & 0,5581 & 0,5709 \\
\hline
\end{tabular}

Ez a tendencia jellemző a pirolízisreakció hatásfokának alakulására (7-10. táblázatok).

7. táblázat. Pirolizisreakció hatásfoka, $\prod_{r}[\%]$

\begin{tabular}{|c|c|c|c|}
\hline $\mathbf{H} / \mathbf{C} ; \mathbf{O} / \mathbf{C}$ & $\mathbf{0 , 4 0}$ & $\mathbf{0 , 4 5}$ & $\mathbf{0 , 5 0}$ \\
\hline $\mathbf{1 , 1 5}$ & - & $34,38 \%$ & $33,32 \%$ \\
\hline $\mathbf{1 , 2 0}$ & - & $36,39 \%$ & $35,18 \%$ \\
\hline $\mathbf{1 , 2 5}$ & $38,78 \%$ & $38,22 \%$ & $36,06 \%$ \\
\hline $\mathbf{1 , 3 0}$ & $40,66 \%$ & $39,54 \%$ & $38,13 \%$ \\
\hline $\mathbf{1 , 3 5}$ & $42,33 \%$ & $41,24 \%$ & $39,67 \%$ \\
\hline $\mathbf{1 , 4 0}$ & $43,09 \%$ & $42,75 \%$ & $41,27 \%$ \\
\hline $\mathbf{1 , 4 5}$ & $45,16 \%$ & $43,94 \%$ & $42,83 \%$ \\
\hline $\mathbf{1 , 5 0}$ & - & - & $43,95 \%$ \\
\hline $\mathbf{1 , 5 5}$ & - & - & $45,69 \%$ \\
\hline $\mathbf{1 , 6 0}$ & - & - & - \\
\hline
\end{tabular}

8. táblázat. Pirolízisreakció hatásfoka, $\eta_{r}$ [\%]

\begin{tabular}{|c|c|c|c|}
\hline $\mathbf{H} / \mathbf{C} ; \mathbf{O} / \mathbf{C}$ & $\mathbf{0 , 5 5}$ & $\mathbf{0 , 6 0}$ & $\mathbf{0 , 6 5}$ \\
\hline $\mathbf{1 , 1 5}$ & $33,12 \%$ & - & - \\
\hline $\mathbf{1 , 2 0}$ & $34,09 \%$ & $33,35 \%$ & - \\
\hline $\mathbf{1 , 2 5}$ & $35,80 \%$ & $34,89 \%$ & - \\
\hline $\mathbf{1 , 3 0}$ & $37,15 \%$ & $36,28 \%$ & $34,58 \%$ \\
\hline $\mathbf{1 , 3 5}$ & $38,75 \%$ & $37,40 \%$ & $36,55 \%$ \\
\hline $\mathbf{1 , 4 0}$ & $40,14 \%$ & $38,99 \%$ & $38,29 \%$ \\
\hline $\mathbf{1 , 4 5}$ & $41,34 \%$ & $40,14 \%$ & $38,88 \%$ \\
\hline $\mathbf{1 , 5 0}$ & $42,35 \%$ & $41,69 \%$ & $40,13 \%$ \\
\hline $\mathbf{1 , 5 5}$ & $43,92 \%$ & $42,70 \%$ & $41,24 \%$ \\
\hline $\mathbf{1 , 6 0}$ & - & $44,24 \%$ & $43,76 \%$ \\
\hline
\end{tabular}

9. táblázat. 10\%-os nedvességtartalom hatása a pirolizisreakció hatásfokára, $\Delta \eta_{r}[\%]$

\begin{tabular}{|c|c|c|c|}
\hline $\mathbf{H} / \mathbf{C} ; \mathbf{O} / \mathbf{C}$ & $\mathbf{0 , 4 0}$ & $\mathbf{0 , 4 5}$ & $\mathbf{0 , 5 0}$ \\
\hline $\mathbf{1 , 1 5}$ & - & $12,91 \%$ & $13,47 \%$ \\
\hline $\mathbf{1 , 2 0}$ & - & $12,89 \%$ & $13,52 \%$ \\
\hline $\mathbf{1 , 2 5}$ & $14,41 \%$ & $12,97 \%$ & $13,79 \%$ \\
\hline $\mathbf{1 , 3 0}$ & $12,74 \%$ & $13,15 \%$ & $13,93 \%$ \\
\hline $\mathbf{1 , 3 5}$ & $12,84 \%$ & $13,42 \%$ & $15,01 \%$ \\
\hline $\mathbf{1 , 4 0}$ & $13,10 \%$ & $13,62 \%$ & $14,35 \%$ \\
\hline $\mathbf{1 , 4 5}$ & $13,23 \%$ & $13,93 \%$ & $14,65 \%$ \\
\hline $\mathbf{1 , 5 0}$ & - & - & $14,96 \%$ \\
\hline $\mathbf{1 , 5 5}$ & - & - & $15,23 \%$ \\
\hline $\mathbf{1 , 6 0}$ & - & - & - \\
\hline
\end{tabular}

10. táblázat. $10 \%$-os nedvességtartalom hatása a pirolizisreakció hatásfokára, $\Delta \eta_{r}[\%]$

\begin{tabular}{|c|c|c|c|}
\hline $\mathbf{H} / \mathbf{C} ; \mathbf{O} / \mathbf{C}$ & $\mathbf{0 , 5 5}$ & $\mathbf{0 , 6 0}$ & $\mathbf{0 , 6 5}$ \\
\hline $\mathbf{1 , 1 5}$ & $13,63 \%$ & - & - \\
\hline $\mathbf{1 , 2 0}$ & $13,96 \%$ & $14,34 \%$ & - \\
\hline $\mathbf{1 , 2 5}$ & $14,18 \%$ & $14,73 \%$ & - \\
\hline $\mathbf{1 , 3 0}$ & $14,48 \%$ & $14,99 \%$ & $15,63 \%$ \\
\hline $\mathbf{1 , 3 5}$ & $14,69 \%$ & $15,63 \%$ & $15,97 \%$ \\
\hline $\mathbf{1 , 4 0}$ & $15,02 \%$ & $15,71 \%$ & $16,12 \%$ \\
\hline $\mathbf{1 , 4 5}$ & $15,40 \%$ & $16,06 \%$ & $16,45 \%$ \\
\hline $\mathbf{1 , 5 0}$ & $15,66 \%$ & $16,35 \%$ & $17,12 \%$ \\
\hline $\mathbf{1 , 5 5}$ & $15,95 \%$ & $16,87 \%$ & $17,17 \%$ \\
\hline $\mathbf{1 , 6 0}$ & - & $17,12 \%$ & $17,41 \%$ \\
\hline
\end{tabular}

A fajlagos fagáztermelésnél eltérő hatás figyelhető meg (11. és 12. táblázat). Ennél 
a kategóriánál mind a $\mathrm{H} / \mathrm{C}$, mind az $\mathrm{O} / \mathrm{C}$ arány növekedése nagyobb fajlagos gáztermelést eredményez. A növekvő nedvességtartalom hatására nagyobb a fajlagos gáztermelés (13. és 14. táblázat), azonban itt a $\mathrm{H} / \mathrm{C}$ és az $\mathrm{O} / \mathrm{C}$ aránypárok fordítottan arányosak.

11. táblázat. Fajlagos gáztermelés mértéke pirolizis esetén, $k_{g t}\left[\mathrm{~kg}_{g a z} / \mathrm{kg}_{\text {fal }}\right]$

\begin{tabular}{|c|c|c|c|}
\hline $\mathbf{H} / \mathbf{C} ; \mathbf{O} / \mathbf{C}$ & $\mathbf{0 , 4 0}$ & $\mathbf{0 , 4 5}$ & $\mathbf{0 , 5 0}$ \\
\hline $\mathbf{1 , 1 5}$ & - & 0,1652 & 0,2200 \\
\hline $\mathbf{1 , 2 0}$ & - & 0,1671 & 0,2268 \\
\hline $\mathbf{1 , 2 5}$ & 0,1538 & 0,1781 & 0,2523 \\
\hline $\mathbf{1 , 3 0}$ & 0,1616 & 0,1980 & 0,2667 \\
\hline $\mathbf{1 , 3 5}$ & 0,1754 & 0,2261 & 0,2884 \\
\hline $\mathbf{1 , 4 0}$ & 0,2012 & 0,2468 & 0,3067 \\
\hline $\mathbf{1 , 4 5}$ & 0,2180 & 0,2759 & 0,3327 \\
\hline $\mathbf{1 , 5 0}$ & - & - & 0,3582 \\
\hline $\mathbf{1 , 5 5}$ & - & - & 0,3794 \\
\hline $\mathbf{1 , 6 0}$ & - & - & - \\
\hline
\end{tabular}

12. táblázat. Fajlagos gáztermelés mértéke pirolizis esetén, $k_{g t}\left[\mathrm{~kg}_{g a \dot{z}} / \mathrm{kg}_{\text {fal }}\right]$

\begin{tabular}{|c|c|c|c|}
\hline $\mathbf{H} / \mathbf{C} ; \mathbf{O} / \mathbf{C}$ & $\mathbf{0 , 5 5}$ & $\mathbf{0 , 6 0}$ & $\mathbf{0 , 6 5}$ \\
\hline $\mathbf{1 , 1 5}$ & 0,2348 & - & - \\
\hline $\mathbf{1 , 2 0}$ & 0,2668 & 0,3002 & - \\
\hline $\mathbf{1 , 2 5}$ & 0,2868 & 0,3339 & - \\
\hline $\mathbf{1 , 3 0}$ & 0,3138 & 0,3561 & 0,4076 \\
\hline $\mathbf{1 , 3 5}$ & 0,3320 & 0,4060 & 0,4312 \\
\hline $\mathbf{1 , 4 0}$ & 0,3599 & 0,4117 & 0,4419 \\
\hline $\mathbf{1 , 4 5}$ & 0,3893 & 0,4375 & 0,4650 \\
\hline $\mathbf{1 , 5 0}$ & 0,4087 & 0,4572 & 0,5089 \\
\hline $\mathbf{1 , 5 5}$ & 0,4296 & 0,4917 & 0,5117 \\
\hline $\mathbf{1 , 6 0}$ & - & 0,5075 & 0,5251 \\
\hline
\end{tabular}

A pirokoksz keletkezése a gázképződéssel fordítottan arányos. Ez az állítás nemcsak matematikailag, hanem azon elv alapján is levezethetö, hogy az alapanyagban található nedvesség- és illóanyag-tartalom a hő hatására gőz/gáz formájában felszabadul, és reagál a karbonnal, ami ezáltal csökkenti a visszamaradó szilárd végtermék mennyiségét.
13. táblázat. $10 \%$-os nedvességtartalom hatása a fajlagos fagáztermelésre, $\Delta k_{g t}\left[\mathrm{~kg}_{g a ́ z} / \mathrm{kg}_{f a}\right]$

\begin{tabular}{|c|c|c|c|}
\hline $\mathbf{H} / \mathbf{C} ; \mathbf{O} / \mathbf{C}$ & $\mathbf{0 , 4 0}$ & $\mathbf{0 , 4 5}$ & $\mathbf{0 , 5 0}$ \\
\hline $\mathbf{1 , 1 5}$ & - & 0,1438 & 0,1384 \\
\hline $\mathbf{1 , 2 0}$ & - & 0,1436 & 0,1377 \\
\hline $\mathbf{1 , 2 5}$ & 0,1448 & 0,1425 & 0,1351 \\
\hline $\mathbf{1 , 3 0}$ & 0,1440 & 0,1405 & 0,1337 \\
\hline $\mathbf{1 , 3 5}$ & 0,1426 & 0,1377 & 0,1335 \\
\hline $\mathbf{1 , 4 0}$ & 0,1400 & 0,1356 & 0,1297 \\
\hline $\mathbf{1 , 4 5}$ & 0,1383 & 0,1327 & 0,1271 \\
\hline $\mathbf{1 , 5 0}$ & - & - & 0,1245 \\
\hline $\mathbf{1 , 5 5}$ & - & - & 0,1224 \\
\hline $\mathbf{1 , 6 0}$ & - & - & - \\
\hline
\end{tabular}

14. táblázat. $10 \%$-os nedvességtartalom hatása a fajlagos fagáztermelésre, $\Delta k_{g t}\left[\mathrm{~kg}_{g a ́ z} / \mathrm{kg}_{f a}\right]$

\begin{tabular}{|c|c|c|c|}
\hline $\mathbf{H} / \mathbf{C} ; \mathbf{O} / \mathbf{C}$ & $\mathbf{0 , 5 5}$ & $\mathbf{0 , 6 0}$ & $\mathbf{0 , 6 5}$ \\
\hline $\mathbf{1 , 1 5}$ & 0,1369 & - & - \\
\hline $\mathbf{1 , 2 0}$ & 0,1337 & 0,1303 & - \\
\hline $\mathbf{1 , 2 5}$ & 0,1317 & 0,1269 & - \\
\hline $\mathbf{1 , 3 0}$ & 0,1290 & 0,1247 & 0,1194 \\
\hline $\mathbf{1 , 3 5}$ & 0,1272 & 0,1196 & 0,1171 \\
\hline $\mathbf{1 , 4 0}$ & 0,1244 & 0,1191 & 0,1160 \\
\hline $\mathbf{1 , 4 5}$ & 0,1214 & 0,1165 & 0,1137 \\
\hline $\mathbf{1 , 5 0}$ & 0,1195 & 0,1146 & 0,1092 \\
\hline $\mathbf{1 , 5 5}$ & 0,1174 & 0,1111 & 0,1090 \\
\hline $\mathbf{1 , 6 0}$ & - & 0,1095 & 0,1077 \\
\hline
\end{tabular}

A 15. és 16. táblázatokból látható, hogy az alapanyag $\mathrm{H} / \mathrm{C}$ és $\mathrm{O} / \mathrm{C}$ arányának növekedése csökkenti a fajlagos koksztermelést. A tüzelőanyag nagyobb fajlagos hidrogénés oxigéntartalma arra utal, hogy az nagyobb mennyiségben tartalmaz illó vegyületeket.

A növekvő nedvességtartalom a gázképződésnek kedvez, így a koksztermelésnél csökkenő tendencia figyelhető meg. A keletkező fajlagos pirolízisolaj mennyisége azon elv szerint határozható meg, hogy a keletkező fajlagos gáz $\left(\mathrm{k}_{\mathrm{gt}}\right)$, koksz $\left(\mathrm{k}_{\mathrm{pk}}\right)$ és olajtermékek $\left(\mathrm{k}_{\mathrm{po}}\right)$ összege egységnyi értéket képvisel.

$$
k_{g t}+k_{p k}+k_{p o}=1
$$


15. táblázat. Fajlagos koksztermelés mértéke pirolizis esetén, $k_{p k}\left[\mathrm{~kg}_{\mathrm{koksz}} / \mathrm{kg}_{f a}\right]$

\begin{tabular}{|c|c|c|c|}
\hline $\mathbf{H} / \mathbf{C} ; \mathbf{O} / \mathbf{C}$ & $\mathbf{0 , 4 0}$ & $\mathbf{0 , 4 5}$ & $\mathbf{0 , 5 0}$ \\
\hline $\mathbf{1 , 1 5}$ & - & 0,4084 & 0,3810 \\
\hline $\mathbf{1 , 2 0}$ & - & 0,4074 & 0,3776 \\
\hline $\mathbf{1 , 2 5}$ & 0,4141 & 0,4019 & 0,3648 \\
\hline $\mathbf{1 , 3 0}$ & 0,4102 & 0,3920 & 0,3576 \\
\hline $\mathbf{1 , 3 5}$ & 0,4033 & 0,3780 & 0,3468 \\
\hline $\mathbf{1 , 4 0}$ & 0,3904 & 0,3676 & 0,3377 \\
\hline $\mathbf{1 , 4 5}$ & 0,3820 & 0,3530 & 0,3247 \\
\hline $\mathbf{1 , 5 0}$ & - & - & 0,3119 \\
\hline $\mathbf{1 , 5 5}$ & - & - & 0,3013 \\
\hline $\mathbf{1 , 6 0}$ & - & - & - \\
\hline
\end{tabular}

16. táblázat. Fajlagos koksztermelés mértéke pirolizis esetén, $k_{p k}\left[\mathrm{~kg}_{\mathrm{koksz}} / \mathrm{kg}_{\text {fal }}\right]$

\begin{tabular}{|c|c|c|c|}
\hline $\mathbf{H} / \mathbf{C} ; \mathbf{O} / \mathbf{C}$ & $\mathbf{0 , 5 5}$ & $\mathbf{0 , 6 0}$ & $\mathbf{0 , 6 5}$ \\
\hline $\mathbf{1 , 1 5}$ & 0,3736 & - & - \\
\hline $\mathbf{1 , 2 0}$ & 0,3576 & 0,3409 & - \\
\hline $\mathbf{1 , 2 5}$ & 0,3476 & 0,3241 & - \\
\hline $\mathbf{1 , 3 0}$ & 0,3341 & 0,3130 & 0,2872 \\
\hline $\mathbf{1 , 3 5}$ & 0,3250 & 0,2880 & 0,2754 \\
\hline $\mathbf{1 , 4 0}$ & 0,3111 & 0,2851 & 0,2701 \\
\hline $\mathbf{1 , 4 5}$ & 0,2963 & 0,2722 & 0,2585 \\
\hline $\mathbf{1 , 5 0}$ & 0,2867 & 0,2624 & 0,2366 \\
\hline $\mathbf{1 , 5 5}$ & 0,2762 & 0,2451 & 0,2352 \\
\hline $\mathbf{1 , 6 0}$ & - & 0,2373 & 0,2285 \\
\hline
\end{tabular}

17. táblázat. $10 \%$-os nedvességtartalom hatása a fajlagos koksztermelésre, $\Delta k_{p k}$ $\left[\mathrm{kg}_{\text {koksz }} / \mathrm{kg}_{\text {fal }}\right]$

\begin{tabular}{|c|c|c|c|}
\hline $\mathbf{H} / \mathbf{C} ; \mathbf{O} / \mathbf{C}$ & $\mathbf{0 , 4 0}$ & $\mathbf{0 , 4 5}$ & $\mathbf{0 , 5 0}$ \\
\hline $\mathbf{1 , 1 5}$ & - & $-0,0714$ & $-0,0687$ \\
\hline $\mathbf{1 , 2 0}$ & - & $-0,0713$ & $-0,0683$ \\
\hline $\mathbf{1 , 2 5}$ & $-0,0719$ & $-0,0707$ & $-0,0671$ \\
\hline $\mathbf{1 , 3 0}$ & $-0,0715$ & $-0,0697$ & $-0,0663$ \\
\hline $\mathbf{1 , 3 5}$ & $-0,0708$ & $-0,0683$ & $-0,0658$ \\
\hline $\mathbf{1 , 4 0}$ & $-0,0695$ & $-0,0673$ & $-0,0643$ \\
\hline $\mathbf{1 , 4 5}$ & $-0,0687$ & $-0,0658$ & $-0,0630$ \\
\hline $\mathbf{1 , 5 0}$ & - & - & $-0,0618$ \\
\hline $\mathbf{1 , 5 5}$ & - & - & $-0,0607$ \\
\hline $\mathbf{1 , 6 0}$ & - & - & - \\
\hline
\end{tabular}

Példaként szemléltetjük három eltérő fajlagos összetételü és változó nedvességtartalmú fafajta pirolízisére kapott eredményeit (17. és 18. táblázatok). A referencia fafajtáknál megfigyelhető, hogy a nagyobb nedvességtartalom növeli a fajlagos energiakihozatal mértékét, ezen keresztül pedig a reakcióhatásfokot, tovább kedvez a fajlagos gázképződésnek, és csökkenti a pirolíziskoksz mennyiségét. Amennyiben a vizsgálati eredményeket összehasonlítjuk a táblázatokból leolvasott, illetve köztes $\mathrm{H} / \mathrm{C}$ és $\mathrm{O} / \mathrm{C}$ arányoknál lineáris interpolációval meghatározott értékeket, akkor megkaphatjuk a táblázatrendszerünk pontosságát.

18. táblázat. $10 \%$-os nedvességtartalom hatása a fajlagos koksztermelésre, $\Delta k_{p k}$ $\left[\mathrm{kg}_{\mathrm{koksz}} / \mathrm{kg}_{\mathrm{fa}}\right]$

\begin{tabular}{|c|c|c|c|}
\hline $\mathbf{H} / \mathbf{C} ; \mathbf{O} / \mathbf{C}$ & $\mathbf{0 , 5 5}$ & $\mathbf{0 , 6 0}$ & $\mathbf{0 , 6 5}$ \\
\hline $\mathbf{1 , 1 5}$ & $-0,0679$ & - & - \\
\hline $\mathbf{1 , 2 0}$ & $-0,0663$ & $-0,0646$ & - \\
\hline $\mathbf{1 , 2 5}$ & $-0,0653$ & $-0,0630$ & - \\
\hline $\mathbf{1 , 3 0}$ & $-0,0640$ & $-0,0618$ & $-0,0592$ \\
\hline $\mathbf{1 , 3 5}$ & $-0,0631$ & $-0,0593$ & $-0,0580$ \\
\hline $\mathbf{1 , 4 0}$ & $-0,0617$ & $-0,0591$ & $-0,0575$ \\
\hline $\mathbf{1 , 4 5}$ & $-0,0602$ & $-0,0578$ & $-0,0563$ \\
\hline $\mathbf{1 , 5 0}$ & $-0,0592$ & $-0,0568$ & $-0,0541$ \\
\hline $\mathbf{1 , 5 5}$ & $-0,0582$ & $-0,0550$ & $-0,0540$ \\
\hline $\mathbf{1 , 6 0}$ & - & $-0,0542$ & $-0,0533$ \\
\hline
\end{tabular}

19. táblázat. Fafajták pirolizise, összefoglalás

\begin{tabular}{|c|c|c|c|}
\hline Fafajta & $\begin{array}{c}\text { Nedvesség } \\
{[\%]}\end{array}$ & $\begin{array}{c}\boldsymbol{e}_{\boldsymbol{k}} \\
{\left[\mathbf{M J} / \mathbf{k g}_{\mathbf{f a}}\right]}\end{array}$ & $\begin{array}{c}\eta_{\mathrm{r}} \\
{[\mathbf{\%}]}\end{array}$ \\
\hline Energiafüz & 0 & 4,4032 & 35,89 \\
\hline Energiafüz & 15 & 5,3056 & 59,79 \\
\hline Bükkfa & 0 & 4,7363 & 40,14 \\
\hline Bükkfa & 20 & 5,8841 & 72,26 \\
\hline Tölgyfa & 0 & 4,5906 & 33,98 \\
\hline Tölgyfa & 23 & 4,6007 & 66,78 \\
\hline
\end{tabular}


20. táblázat. Fafajták pirolízise, összefoglalás

\begin{tabular}{|c|c|c|c|}
\hline Fafajta & $\begin{array}{c}\text { Nedves- } \\
\text { ség [\%] }\end{array}$ & $\begin{array}{c}\boldsymbol{k}_{\boldsymbol{g t}} \\
{\left[\mathbf{k g}_{\mathbf{g}} / \mathbf{k g}_{\mathrm{fa}}\right]}\end{array}$ & $\begin{array}{c}\boldsymbol{k}_{\boldsymbol{p k}} \\
{\left[\mathbf{k g}_{\mathbf{p k}} / \mathbf{k g}_{\mathrm{fa}}\right]}\end{array}$ \\
\hline Energiafüz & 0 & 0,3846 & 0,2988 \\
\hline Energiafüz & 15 & 0,5673 & 0,2082 \\
\hline Bükkfa & 0 & 0,4375 & 0,4074 \\
\hline Bükkfa & 20 & 0,6705 & 0,2648 \\
\hline Tölgyfa & 0 & 0,2735 & 0,3543 \\
\hline Tölgyfa & 23 & 0,5794 & 0,2011 \\
\hline
\end{tabular}

\section{Következtetések}

A termokinetikai modellvizsgálatok azt az eredményt hozták, hogy a fás szárú biomassza pirolízissel történő hasznosítás során a nedvességtartalom növekedése a fajlagos energiakihozatalt (5-6. táblázat), a kémiai hatásfokot (9-10. táblázat) és a fajlagos fagáztermelést (13-14. táblázat) pozitív irányba változtatja. A nagyobb nedvességtartalom nagyobb energiatartalmú és mennyiségü fagázt eredményez. A pirolízisolaj és a pirokoksz mennyisége (17-18. táblázat) a nedvességtartalommal fordított arányban áll.

\section{Szakirodalmi hivatkozások}

[1] BASU, P.: Biomass gasification, pyrolysis and torrefaction, Practical design and theory, Second edition, Elsevire, San Diego, 2013. p. 529.

[2] SZUHI, A.: Az új termikus technológiák környezeti hatásai (pirolizis, elgázositás és plazma technológia). Humusz Szövetség és Vidék-fejlesztési Minisztérium 2013. p. 14.

[3] WAMPLER, T., P.: Applied pyrolysis handbook. Taylor \& Francis, Secound edition, 2007. p. 285.

[4] SZUHI, A.: Új termikus technológiák és hagyományos hulladékégetök. Környezetvédelmi-Vízügyi Minisztérium, 2009. p. 36.

[5] HILL, T. \& DOWEN, S.: Pyrolysis and gasification. Briefing (Draf 2), UK Without Incineration Network (UKWIN), 2010. p. 9.

[6] HANAOKA, T., INOUE UNO, S., OGI, T., MINOWA, T: Effect of wood biomass components on air-steam gasification.
Biomass and Bioenergy, Vol. 28. No. 1. 2005, pp. 69-75.

[7] HOGG, R.: Energy from waste by pyrolysis and gasification the experience and performance of an operational plant. Solid Waste Management, 2007, pp. 385-392.

[8] HELSEN, L., BOSMANS, A.: Waste-toEnergy through thermochemical processes: matching waste with process. Proceedings of the International Academic Symposium on Enhanced Landfill Mining, HouthalenHelchtern, Belgium, 2010, pp. 133-180.

[9] ZAINAL, Z., A., ALI, R., LEAN, C., H., SEETHARAMU, K., N.: Prediction of perfor-mance of a downdraft gasifier using equilibrium modelling for different biomass material. Energy Conversion and Management. Vol. 42. 2001. pp. 1499-1515.

[10] RED, T., B., DAS, A.: Handbook of biomass downdraft gasifier engine systems, Solar Energy Research Ins., 1988. p. 148.

[11] WANG, Y., KINOSHITA, C. M.: Kinetic model of biomass gasification. Solar Energy, Vol. 51. No. 1. 1993, pp. 19-25.

[12] MOUNTOURIS, A., VOUTSAS, E., TASSIOS, D.: Solid waste plasma gasification: equilibrium model development and exergy analysis. Energy Conversion and Management. Vol. 47. 2006. pp. 1723-1737.

[13] HATZILYBERIS, K. S.: Design of an indirect heat rotary kiln gasifier. Fuel Processing Technology. 92, 2011. pp. 2429-2454.

[14] MORLY, C.: Method for calculating equilibrium compositions at specified temperature, Gaseq, a chemiacal equilibrium program for windows. www.gaseq.co.uk 2005. p. 6.

[15] PATTERSON, M. G.: What is energy efficiency? Concepts, indicators and methodological issues. Energy Policy. Vol. 24, No. 5. pp. 377-390. 1996.

[16] RAJVANSHI, K., A.: Biomass gasification. Alternative Energy in Agriculture. Vol. 2. No. 4. 1986. pp. 83-102.

[17] SCHUSTER, G., LÖFFER, G., WEIGEL, K., HOFBAUER, H.: Biomass steam gasification - an extensive parametric modeling study. Bioresource Technology. Vol. 77. 2001.pp. 71-79. 
[18] GYULAI, I.: A biomassza dilemma, Magyar Természetvédök Szövetsége, Föld Barátai Magyarország, 2010. p. 116. 